\title{
Not Calling the Tune: Australian Taxpayer Subsidies to Parties' Election Campaigns
}

\author{
Ian Farrow
}

$\mathrm{H}$

OW many Australians are aware that when they cast their ballots at a Commonwealth general election they are also facilitating taxpayer contributions to the political parties?

Taxpayer funding of political parties was one of a number of significant changes to the electoral system introduced by the Hawke Government in 1983 . The changes comprised:

- expanding the size of the federal parliament: the House of Representatives by 23 seats (to 148) and the Senate by 12 seats (to 76);

- establishing a system for the registration of political parties with the Australian Electoral Commission, enabling them to have their party name printed adjacent to their candidates on ballot papers;

- providing the registered political parties with access to the electoral roll in electronic format to facilitate direct mail operations: a privilege that is not available to other organisations or individuals;

- modifying the voting system for the Senate, so enabling party machines to control more tightly the flow of preferences through an 'above the line' group ticket voting system;

- requiring political parties to disclose campaign donations above a certain level; and

- introducing taxpayer funding of election campaigns.

In 1983/84 the first taxpayer funding scales were set at 66 cents (then equivalent to two postage stamps) for each first-preference House of Representatives vote and 33 cents for each first-preference Senate vote. Political parties were required to account for their expenditure. Although they were prohibited from receiving more funding than they had actually spent on their election campaigns, the major political parties easily outspent whatever they later received in taxpayer funding. 
The first Commonwealth election to which these changes applied occurred in 1984 , and resulted in payments to the political parties of $\$ 7.5 \mathrm{~m}$. As the original funding scales were later indexed to the Consumer Price Index, by the time of the 1993 Commonwealth election subsidies amounted to one dollar for each House of Representatives first-preference vote and 50 cents for each Senate first-preference vote. Taxpayer subsidies to the political parties following the 1993 election amounted to approximately $\$ 15 \mathrm{~m}$.

\section{Taxpayer Funding Doubled}

Taxpayer funding of election campaigns was doubled in 1995 to more than $\$ 30$ million (see Table 1), in time for the 1996 Commonwealth election.

The 1995 legislation increased taxpayer funding to $\$ 1.50$ (indexed) for firstpreference votes in both the House of Representatives and the Senate. By the time of the 1996 election, indexation had increased this amount to $\$ 1.57$. The legislation also removed the requirement that taxpayer funding be limited to the amount declared as campaign expenditure, thus making it possible for subsidies to exceed campaign costs. No moves were made at the same time to restore the repealed subsection 329(2) of the Electoral Act that subjected political parties to the same standards that applied to the private sector requiring 'truth in advertising', even though the Dissenting Report of the Joint Standing Committee on Electoral Matters by Opposition parties after the 1993 election had asserted that

$\ldots$ if some of the misrepresentations which occur during election campaigns were to happen in the private sector, the perpetrators would find themselves liable to prosecution under the Trade Practices Act. (1994:164)

The legislative changes to the Electoral Act strongly suggested collusive behaviour between the major beneficiaries in the Australian Labor Party, the Liberal and National Parties and the Australian Democrats. The sole dissent to this arrangement came from the Western Australian Greens, with Senator Christabel Chamarette asserting that

This is a disgraceful rort which the public has not had a chance to debate because the deal was kept behind closed doors until recently. Not even the Joint Standing Committee on Electoral Matters was consulted on the proposed changes. (Sydney Morning Herald, 21 April 1995)

At an estimated total cost of $\$ 100 \mathrm{~m}$, the 1996 Commonwealth election was the most expensive in Australian history (Australian Financial Review, 22 January 1996). Taxpayer funding provisions formed a significant component of the increased cost.

Table 1 suggests that some political parties made slight losses due to high levels of campaign expenditure. But taxpayer funding is in addition to the millions of dollars in campaign contributions solicited from other sources such as businesses 
and trade unions. The Liberal Party, the Australian Labor Party, and the National Party reportedly received almost $\$ 39 \mathrm{~m}, \$ 30.4 \mathrm{~m}$ and $\$ 5.5 \mathrm{~m}$ respectively in campaign donations before the 1996 election (Australian Financial Review, 4 February 1997). The available data strongly suggest that some political parties made significant profits from the 1996 election through a combination of campaign contributions and taxpayer funding.

\section{Table 1}

1996 Commonwealth election: taxpayer funding of, and declared expenditure by, political parties (A\$)

\begin{tabular}{lrr}
\hline \multicolumn{1}{c}{ Political parties } & Taxpayer funding & Declared expenditure \\
\hline Liberal / National Parties & $15,610,253$ & $16,949,734$ \\
Australian Labor Party & $12,856,383$ & $13,806,144$ \\
Australian Democrats & $2,968,965$ & $1,615,648$ \\
Greens & 447,748 & 397,527 \\
Others & 271,451 & 659,471 \\
& & $33,428,524$ \\
\hline
\end{tabular}

Source: Australian Electoral Commission web site: http://www.aec.gov.au/funding.html

\section{The 1996 Oxley Campaign}

The 1996 campaign in the House of Representatives electorate of Oxley provided a good example of the enthusiasm with which the political parties pursue taxpayer funding. Although Pauline Hanson was disendorsed by the Liberal Party following her comments about Aborigines, she remained officially nominated by the Liberal Party, and on the ballot papers the word 'Liberal' remained adjacent to her name. Following the election, the Liberal Party received $\$ 55,000$ from the Australian Electoral Commission in respect of votes cast for a disendorsed candidate. Mrs Hanson is taking legal action against the Liberal Party to recover this amount, in order to cover $\$ 12,000$ of campaign expenditure (which the Liberal Party has offered her) and to contribute the balance towards the purchase of a new police car for the electorate (Australian Financial Review, 10 October 1996).

\section{The Impact of Compulsory Voting}

Australia is one of the few democracies to make voting compulsory. Since support for either the ALP or the Liberal-National Coalition rarely falls below 40 per cent, 
the voter participation rate secured by compulsory voting combines with taxpayer funding effectively to provide the political parties with financial security.

The Dissenting Report (by members of the Liberal and National Parties in Opposition) of the Joint Standing Committee on Electoral Matters commented:

Compulsory voting is not the democratic norm. No other English-speaking democracy has it, nor does any other major democracy. In principle it is contrary to the spirit of democracy, which is based on the right to vote (or not to vote). (1994:157)

\section{Subsidising Television Stations}

Taxpayer funding has been defended by the National Secretary of the Australian Labor Party, Gary Gray, as compensation for 'the service that we provide in connecting the political leadership to the grass roots' (Gray, 1996:53). In fact, this is code for extra television election advertising and the assembling of direct mail databases on Australian citizens. As Stephen Mills (1986:129) notes,

By virtually guaranteeing the Parties a minimum reimbursement, public funding means they can spend other funds with greater ease than before. This means costs will continue rising. And by failing to place restrictions on the way Parties spend the public monies, the new rules ensure TV proprietors will continue to reap a good harvest every election time. ... Under the public funding rules the public is effectively being hood-winked. Public funding of election campaigns mainly means public funding of TV stations.

Mills further observes that television stations charge political clients more than they would charge normal commercial advertisers, both because of the sudden demand requirements by political parties to schedule advertising during the election campaign period and the use of standard advertising rates. If the television stations provided the political parties with discounts on their standard rates, as they might do for other high volume advertisers, the Electoral Act would require them to declare the discounts as de facto donations to the political parties.

\section{Reforming the Electoral System}

Taxpayer funding of election campaigns is a symptom of waning public involvement in political parties. All Australian political parties are experiencing a long-term membership decline, occasionally interrupted by frantic recruitment in safe electorates prior to party preselections. Taxpayer funding amounts to a substitute source of income for political parties; it also renders party members and supporters even less relevant to the electoral process.

The present electoral system is increasingly designed to serve the interests of the elected rather than the electors. It could be substantially reformed by abolishing 
compulsory voting, rescinding the taxpayer funding of election campaigns and ensuring that the political parties are subject to the same advertising standards as those that apply to the private sector. It is, however, very unlikely that the Commonwealth parliament will undertake such reforms in the foreseeable future. In particular, it is unlikely to abolish the taxpayer funding of political parties, even in the interests of fiscal consolidation.

It used to be said in connection with donations to political parties that 'those who pay the piper call the tune'. If taxpayers at present have no choice but to continue funding political parties (which are private organisations), perhaps they could successfully demand greater control over how their taxes are spent. They could insist on two changes: that political parties adopt minimum standards for internal elections and procedures as a condition of entitlement to taxpayer funding; and that the Australian Electoral Commission publicise details of the operation of taxpayer funding in conjunction with the normal voter information campaign during Commonwealth elections. An electorate better informed about the present system would undoubtedly demand further change.

\section{References}

Gray, G. (1996), 'Labor and the 1996 Federal Election', The Sydney Papers 8(3): 49-55.

Joint Standing Committee on Electoral Matters (1994), Report of Inquiry into the conduct of the 1993 Federal Election and matters related thereto, AGPS, Canberra.

Mills, S. (1986), The New Machine Men, Penguin Books Australia, Ringwood. 